Article

\title{
Encapsulated Microparticles of $(1 \rightarrow 6)-\beta$-D-Glucan Containing Extract of Baccharis dracunculifolia: Production and Characterization
}

\author{
Genice Iurckevicz ${ }^{1}{ }^{(0)}$, Débora Dahmer ${ }^{2}$, Vidiany A. Q. Santos ${ }^{2}$, Vaclav Vetvicka ${ }^{3}$, \\ Aneli M. Barbosa-Dekker ${ }^{4}$, Robert F. H. Dekker ${ }^{5}{ }^{\circ}$, Carlos Ricardo Maneck Malfatti ${ }^{1}$ and
} Mário A. A. da Cunha ${ }^{2, *} \mathbb{C}$

1 Chemistry Department, Universidade Estadual do Centro Oeste, Rua Simeão Varela de Sá, 03, Vila Carli, CEP, Guarapuava, PR 85040-080, Brazil; genice.iur@gmail.com (G.I.); crmalfatti@gmail.com (C.R.M.M.)

2 Chemistry Department, Universidade Tecnológica Federal do Paraná, Via do Conhecimento, Km 1, CEP, Pato Branco, PR 85503-390, Brazil; debora-dahmer@hotmail.com (D.D.); vidianyqueiroz@yahoo.com.br (V.A.Q.S.)

3 Department of Pathology, University of Louisville, 511 S. Floyd St, Louisville, KY 40292, USA; v0vetv01@louisville.edu

4 Chemistry Department, CCE, Universidade Estadual de Londrina, CEP, Londrina, PR 86057-970, Brazil; anelibarbosa@gmail.com

5 Programa de Pós-Graduação em Engenharia Ambiental, Universidade Tecnológica Federal do Paraná, Câmpus Londrina, CEP, Londrina, PR 86036-370, Brazil; xylanase@gmail.com

* Correspondence: mcunha@utfpr.edu.br; Tel.: +55-463-220-2511; Fax: +55-463-220-2500

Academic Editor: Tran Dang Xuan

Received: 6 May 2019; Accepted: 31 May 2019; Published: 3 June 2019

\begin{abstract}
Glucans are biomacromolecules well known, among other biological activities, for their immunomodulatory potential. Similarly, extracts of Baccharis dracunculifolia also possess biological properties and are used in folk medicine for the treatment of inflammation, ulcers, and hepatic diseases. Microparticles containing ( $1 \rightarrow 6)-\beta$-D-glucan (lasiodiplodan) and B. dracunculifolia extract were produced and characterized. A $2^{3}$ factorial design was employed to define the conditions of production of microparticles by atomization. Lasiodiplodan associated with maltodextrin and gum arabic was studied as a matrix material. Microparticles of $0.4 \mu \mathrm{m}$ mean size and high phenolics content (3157.9 $\mu \mathrm{g}$ GAE/g) were obtained under the optimized conditions. The microparticle size ranged from 0.23 to $1.21 \mu \mathrm{m}$, and the mathematical model that best represented the release kinetics of the extract was the Korsmeyer-Peppas model. Diffusional exponent (n) values of 0.64 at pH 7.7 and 1.15 at $\mathrm{pH} 2.61$ were found, indicating particles with a non-Fickian or anomalous transport system, and Super Case II transport, respectively. Thermal analysis indicated that the microparticles demonstrated high thermal stability. The X-ray diffraction analyses revealed an amorphous structure, and HPLC-DAD analysis showed microparticles rich in phenolic compounds: caffeic acid, p-coumaric acid, and catechin. The microparticles obtained comprise a new biomaterial with biological potential for applications in different fields.
\end{abstract}

Keywords: bioactivity; encapsulation; experimental design; natural products

\section{Introduction}

Medicinal plants are part of the history of human evolution. More than $50 \%$ of all drugs used in modern medicinal treatments are composed of natural products and derivatives thereof [1]. The physicochemical stability is a determining factor in the quality of plant extracts and the transformation of these into dry-powdered form is the most desirable strategy, considering that this form improves its stability and facilitates the manipulation of the material [2]. Techniques for the incorporation of 
plant extracts within polymer matrices have indicated a good alternative for the improvement of the functionality of medicinal plant extracts [3]. The spray-drying process that involves the dispersion of material inside a coated material is a technique that has been widely used in recent years for the incorporation of extracts into polymer matrices [4].

Baccharis dracunculifolia, popularly known in Brazil as alecrim-do-campo (field rosemary) or vassourinha do campo, is a medicinal plant used to treat human disease conditions and from which green propolis is produced by honeybees [5-7]. Several biological properties related to $B$. dracunculifolia, including antidiabetic [8], anti-inflammatory [7], bactericidal [9], and antioxidant [10] activities, have been reported in the scientific literature.

The combination of natural products can make it possible to obtain biomaterials with new potential biological functions. In this sense, the association of plant extracts with microbial $\beta$-glucans may offer a promising strategy for obtaining new drugs. $\beta$-Glucans are carbohydrate biopolymers constituted of repeat D-glucose monomers linked by specific $\beta$-glycosidic bonds [11]. These macromolecules have attracted attention from the pharmaceutical industry for their biological functions that can include immunomodulatory, antimutagenic, anticarcinogenic, hypoglycemic, and hypocholesterolemic properties [12]. More recently, D-glucans have been studied as a support, adjuvant or in combination with other materials in drug delivery systems [13]. It is important to note that modified-release drug delivery systems can improve drug efficacy and contribute to the increased bioavailability, solubility, pharmacological activity, stability, and protection against chemical degradation $[3,14]$.

Spray-drying is a technique that has been widely used in the development of modified release systems $[15,16]$. It is a rapid process that does not involve severe heat treatment; therefore, it is a suitable method to preserve biological products, including temperature sensitive products, without their degradation; it also allows for storage at room temperature $[17,18]$. It is an instantaneous process where spherical and uniform samples can be obtained, and the process can be easily scaled up. Thermal degradation, nutrient loss, and denaturation are minimal, allowing maximum retention of the active principles. Spray-drying is a technique more economical than lyophilization (four to seven times less costly); it also allows coating, complex coacervation, and drying of two different feed solutions during the process [19].

Considering that medicinal plant extracts have been little studied in modified-release systems and that the combination of these with $\beta$-glucans could promote obtaining biomaterials with new biological functions, the present study was aimed towards the production of microparticles containing extracts of $B$. dracunculifolia and the fungal exopolysaccharide $\beta$-glucan (lasiodiplodan) from Lasiodiplodia theobromae matrix metalloproteinase inhibitors (MMPI).

The study included the development and characterization of the microparticles obtained by atomization application using the spray-drying process, and the evaluation of the antioxidant potential and of the kinetics of the release of $B$. dracunculifolia extract from the encapsulated microparticles.

\section{Results and Discussion}

\subsection{Encapsulation Yield}

The effects of the studied variables in the experimental design on the encapsulation yield were plotted in Pareto charts as shown in Figure 1. At a confidence level of $95 \%(p<0.15)$ none of the factors examined had a significant effect on the yield of microparticles produced (Figure 1A). However, considering an $85 \%$ confidence level $(p<0.15)$, the concentration of $(1 \rightarrow 6)-\beta$-D-glucan had a significant negative effect on yield (Figure 1B). Within this confidence interval, the increase in $\beta$-glucan concentration in the encapsulation mixture did not contribute to the yield of the microparticle production. This phenomenon might be explained by increased viscosity of the encapsulation system as a function of the increased concentration of lasiodiplodan. In the microencapsulation process by spray-drying, the viscosity of the system should be low enough to prevent air inclusion in the particles [20,21]. 

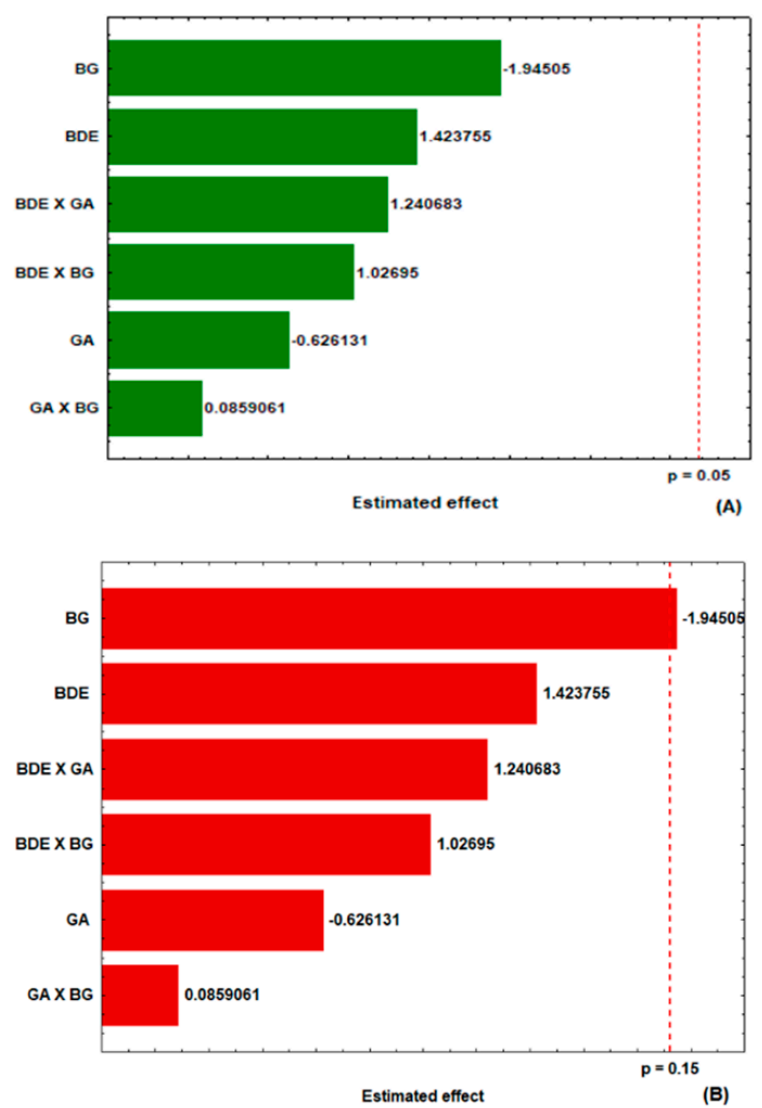

Figure 1. Estimated effects of the concentrations of $\beta$-glucan (BG), gum arabic (GA), and B. dracunculifolia extract (BDE) on the encapsulation yield of the microparticles at the $95 \%(\mathbf{A})$ and $85 \%$ (B) confidence levels.

\subsection{Total Phenolic Content in the Microparticles}

As was observed in the encapsulation yield at a 95\% confidence level $(p<0.05)$, no factor had a significant effect on the total phenolic content (Figure 2A) of the microparticles. However, on decreasing the statistical confidence interval to $85 \%(p<0.15)$, the variable concentration of $B$. dracunculifolia extract (BDE) showed a statistically significant positive effect (Figure 2B).

In the experimental runs where higher concentrations of BDE (5\%) were used, microparticles with higher concentrations of total phenolics were produced (Table 1). In fact, plant extracts contain high concentrations of phenolic compounds, which are secondary plant metabolites [22]. Similar contents of total phenolics were found in run $2(3154.90 \mu \mathrm{g} \mathrm{GAE} / \mathrm{g})$ and run $6(3157.90 \mu \mathrm{g} \mathrm{GAE} / \mathrm{g})$ (Table 1). The encapsulation conditions employed in these factorial design experiments were similar, differing only in relation to the $\beta$-glucan (lasiodiplodan) content employed. In run $2,2 \%$ of $\beta$-glucan was used, while in run 6 , a concentration of $5 \%$ was used.

Considering the objective of obtaining a biomaterial rich in bioactive compounds, the conditions used in experimental run 6 were assumed to be the best condition for the production of microparticles incorporating the extract of $B$. dracunculifolia and $(1 \rightarrow 6)-\beta$-D-glucan. It is noteworthy that higher concentrations of $\beta$-glucan (1.5\%) were employed in this condition, which is interesting considering the biological and functional properties of glucans. In addition, lower cost microparticles could be produced without the incorporation of gum arabic. 

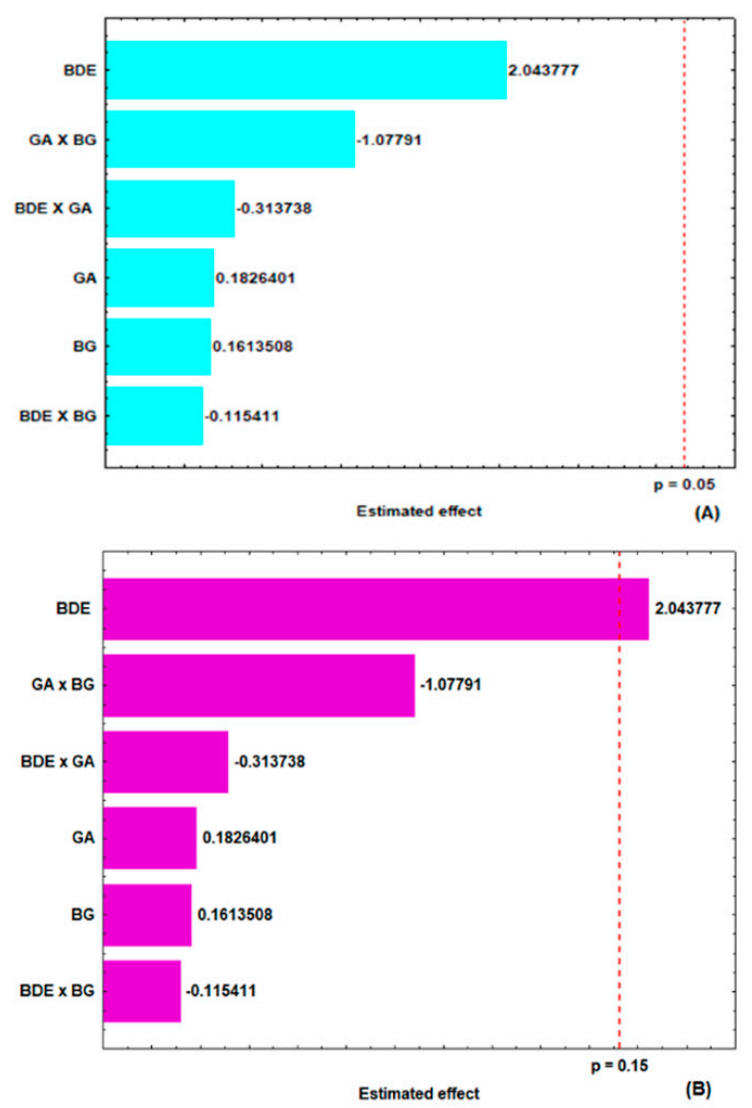

Figure 2. Estimated effects of the concentrations of $\beta$-glucan (BG), gum arabic (GA) and B. dracunculifolia extract (BDE) on the total phenolic content of the microparticles at the $95 \%$ (A) and $85 \%$ (B) confidence levels.

Table 1. Experimental arrangement based on a statistical $2^{3}$ full factorial design.

\begin{tabular}{|c|c|c|c|c|c|c|c|}
\hline \multirow{3}{*}{ Runs } & \multicolumn{3}{|c|}{ Independent Variables } & \multicolumn{4}{|c|}{ Dependent Variables } \\
\hline & \multirow[t]{2}{*}{$B G *(\%)$} & \multirow[t]{2}{*}{$\mathrm{GA}^{\#}(\%)$} & \multirow[t]{2}{*}{ BDE \& $(\%)$} & Total Phenolics & Size & $\begin{array}{l}\text { Polydispersity } \\
\text { Index }\end{array}$ & $\begin{array}{c}\text { Zeta } \\
\text { Potential }\end{array}$ \\
\hline & & & & $(\mu \mathrm{g} \mathrm{GAE} / \mathrm{g})$ & $(\mu \mathrm{m})$ & (PdI) & $1(\mathrm{mV})$ \\
\hline 1 & $0.5(-1)$ & $0.0(-1)$ & $2.0(-1)$ & $762.40 \pm 0.0$ & $0.29 \pm 0.2$ & $0.57 \pm 0.02$ & $19.47 \pm 2.5$ \\
\hline 2 & $0.5(-1)$ & $0.0(-1)$ & $5.0(1)$ & $3154.90 \pm 4.5$ & $0.24 \pm 0.1$ & $0.55 \pm 0.04$ & $19.83 \pm 0.4$ \\
\hline 3 & $0.5(-1)$ & $10(1)$ & $2.0(-1)$ & $2556.40 \pm 26.9$ & $0.37 \pm 0.2$ & $0.79 \pm 0.2$ & $18.87 \pm 0.9$ \\
\hline 4 & $0.5(-1)$ & $10(1)$ & $5.0(1)$ & $3040.00 \pm 20.9$ & $0.27 \pm 0.2$ & $0.57 \pm 0.1$ & $17.27 \pm 0.9$ \\
\hline 5 & $1.5(1)$ & $0.0(-1)$ & $2.0(-1)$ & $2410.10 \pm 11.9$ & $0.38 \pm 0.2$ & $0.70 \pm 0.07$ & $15.70 \pm 1.0$ \\
\hline 6 & $1.5(1)$ & $0.0(-1)$ & $5.0(1)$ & $3157.90 \pm 22.4$ & $0.40 \pm 0.2$ & $0.72 \pm 0.07$ & $18.53 \pm 2.3$ \\
\hline 7 & $1.5(1)$ & $10(1)$ & $2.0(-1)$ & $1277.30 \pm 29.0$ & $0.64 \pm 0.4$ & $0.79 \pm 0.3$ & $18.80 \pm 4.0$ \\
\hline 8 & $1.5(1)$ & $10(1)$ & $5.0(1)$ & $3098.20 \pm 10.4$ & $0.37 \pm 0.2$ & $0.75 \pm 0.02$ & $25.03 \pm 3.2$ \\
\hline 9 & $1.0(0)$ & $5.0(0)$ & $3.5(0)$ & $1992.20 \pm 6.0$ & $1.2 \pm 0.7$ & $1.00 \pm 0.0$ & $16.90 \pm 2.1$ \\
\hline 10 & $1.0(0)$ & $5.0(0)$ & $3.5(0)$ & $1146.00 \pm 10.4$ & $0.57 \pm 0.3$ & $0.89 \pm 0.1$ & $16.57 \pm 2.8$ \\
\hline 11 & $1.0(0)$ & $5.0(0)$ & $3.5(0)$ & $1499.70 \pm 9.0$ & $0.72 \pm 0.4$ & $0.97 \pm 0.06$ & $15.37 \pm 1.9$ \\
\hline 12 & $1.0(0)$ & $5.0(0)$ & $3.5(0)$ & $2983.30 \pm 3.0$ & $0.88 \pm 0.5$ & $0.89 \pm 0.2$ & $17.17 \pm 0.4$ \\
\hline
\end{tabular}

Concentrations of * BG: $\beta$-glucan (lasiodiplodan), ${ }^{*}$ GA: gum arabic, and \& BDE: B. dracunculifolia extract.

\subsection{Antioxidant Activity}

The antioxidant activity found in the microparticles sample obtained from run 6 is shown in Table 2. The microparticles showed scavenging potential of both the DPPH $(33.6 \mu \mathrm{mol}$ Trolox/g) and the ABTS cation radicals ( $24 \mu \mathrm{mol}$ Trolox/g), and appreciable antioxidant potential for ferric ion reduction (FRAP: $212.2 \mu \mathrm{mol} \mathrm{FeSO} \cdot 7 \mathrm{H}_{2} \mathrm{O} / \mathrm{g}$ ). 
Table 2. The antioxidant activity of the microparticles produced by experimental run 6 as expressed using different methods of measurement.

\begin{tabular}{cc}
\hline Method & Antioxidant Activity \\
\hline DPPH $^{*}$ & $33.6 \mu \mathrm{mol} \mathrm{Trolox} / \mathrm{g} \pm 0.7$ \\
ABTS $^{\#}$ & $24 \mu \mathrm{mol} \mathrm{Trolox} / \mathrm{g} \pm 0.2$ \\
FRAP $^{\&}$ & $212.2 \mu \mathrm{mol} \mathrm{FeSO}$ \\
\hline
\end{tabular}

${ }^{*}$ DPPH and \# ABTS scavenging activities expressed as $\mu \mathrm{mol}$ Trolox equivalents $/ \mathrm{g} ;{ }^{\text {\& }} \mathrm{FRAP}$ reducing power expressed as $\mu \mathrm{mol} \mathrm{FeSO}_{4} \cdot 7 \mathrm{H}_{2} \mathrm{O} / \mathrm{g}$.

\subsection{Particle Size and Zeta Potential}

Table 1 shows the average size, polydispersity index and zeta potential of the microparticles formed through the experimental statistical design. None of the independent variables studied showed significant effects on microparticle size (Figure 3). The microparticles ranged in size from $0.24 \mu \mathrm{m}$ (run 2 sample) to $1.21 \mu \mathrm{m}$ (run 9 sample); the run 6 sample was obtained using the optimal spray-drying conditions (assumed to be the best) and showed a particle mean size of $0.4 \mu \mathrm{m}$.

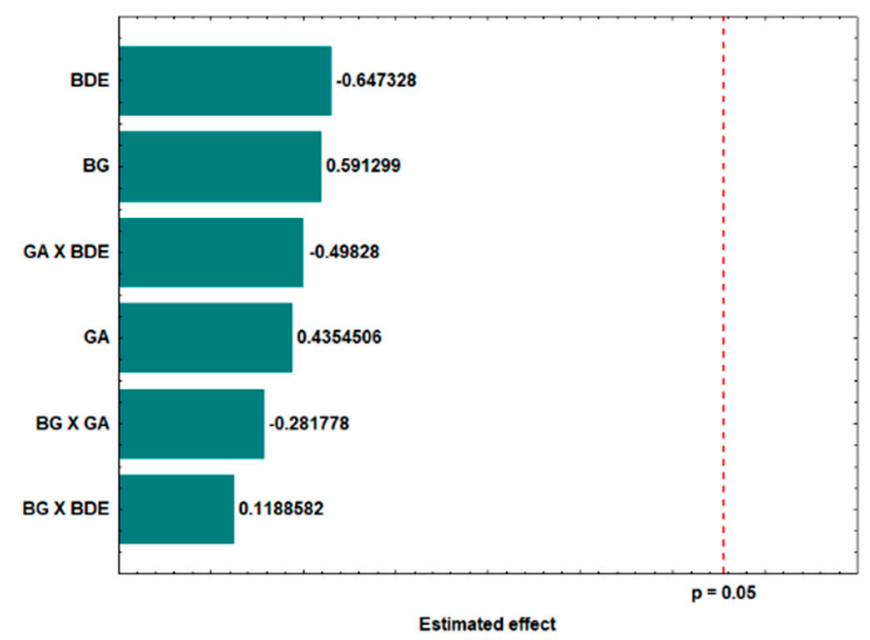

Figure 3. Estimated effects of the concentrations of $\beta$-glucan (BG), gum arabic (GA), and B. dracunculifolia extract (BDE) on the size distribution of the microparticles formed at the $95 \%$ confidence level $(p=0.05)$.

Larger dimensions (mean diameter range, 7.0-11.5 $\mu \mathrm{m}$ ) were reported by Carvalho et al. [23] in microparticles containing jussara (Euterpe edulis) extract, when using gum arabic and maltodextrin as matrix materials. Similarly, Krishnaiah et al. [24] obtained microparticles of Morinda citrifolia Linn extract encapsulated in maltodextrin and carrageenan with mean diameters (range, 2-5 $\mu \mathrm{m}$ ) greater than that found in our study. Li et al. [17] studied five matrix materials (maltodextrin, gum arabic, polyvinyl alcohol, whey protein, and modified starch) using spray-drying technology for lipid encapsulation. Particles with mean sizes that ranged from $1 \mu \mathrm{m}$ to $350 \mathrm{~nm}$ were obtained [17].

The polydispersity index (PdI) represents the varied particle size distribution, and can range from zero (0) in uniform particles to 1.0 in polydisperse particles [25]. In our study, we found a rather large distribution of particle sizes (0.5-1.0). This is possibly related to the high viscosity of the mixture subjected to spray-drying, which also influenced the production yield of the microparticles. In fact, the composition of the matrix material may interfere in the production yield of the microparticles as well as the polydispersity index. In addition, the nature of the matrix material, the concentration of the spray-dried solution, and the location of collection on the spray-drying equipment can influence the size of the microparticles [17].

Zeta potential (ZP) is a physicochemical parameter that reflects the electrical potential of particles and provides information about their physical stability. $\mathrm{ZP}$ is influenced by the dispersion medium and composition of the particle, and when above $\pm 30 \mathrm{mV}$, the surface charges avoid microparticle 
aggregation and indicate a stable suspension [26]. From the results shown in Table 1 and Figure 4A,B, no factor had a significant effect of first (main effect) or second (interaction of two factors) order on this response at the $95 \%$ confidence level $(p<0.05)$. On the other hand, when analyzing the interaction effects between the concentrations of $\beta$-glucan and gum arabic at the $90 \%$ confidence level $(p<0.10)$, a positive effect on the ZP was observed (Figure 4B). In this context, higher concentrations of $\beta$-glucan and gum arabic could contribute to obtaining microparticles with higher ZP.
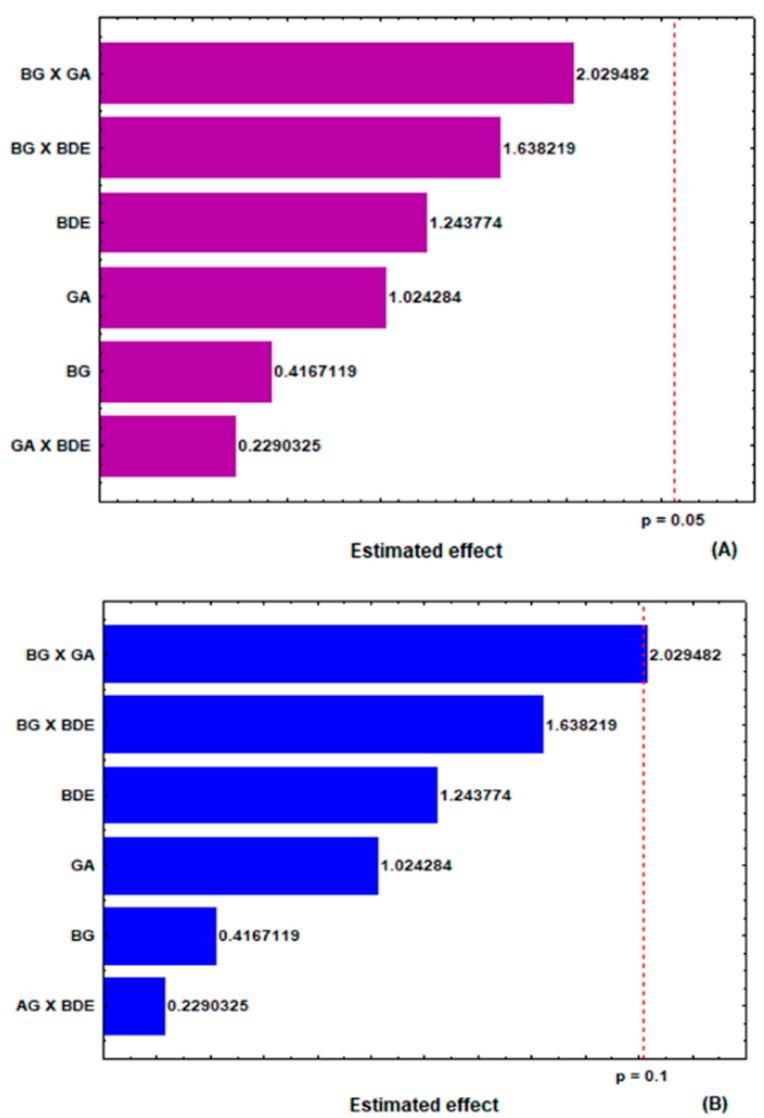

Figure 4. Estimated effects of the concentrations of $\beta$-glucan (BG), gum arabic (GA) and B. dracunculifolia extract (BDE) on the microparticles zeta potential at the $95 \%(A)$ and $90 \%$ (B) confidence levels.

The microparticles produced presented a $\mathrm{ZP}$ that ranged from -15.7 (central point) to $-25 \mathrm{mV}$ (run 8; Table 1). In experimental run 6, where the highest concentrations of both $\beta$-glucan and BDE were employed, a ZP value of $-18.53 \mathrm{mV}$ was observed. Gomes et al. [27] reported on maltodextrin and gum arabic particles coated with egg yolk and a bilayer composed of $\alpha$-phosphatidylcholine and stearylamine, and found a ZP of $56 \mathrm{mV}$. However, when only gum arabic and maltodextrin were employed as encapsulating agents, a negative $\mathrm{ZP}$ resulted $(-16 \mathrm{mV})$. According to these authors, the negative charge on the surface of those microparticles was attributed to the carboxyl groups of glucuronic acid present in gum arabic, which at neutral $\mathrm{pH}$ are deprotonated in ionized form [27].

\subsection{Thermal and X-ray Diffraction Analyses}

Figure 5 shows the profiles of thermogravimetry and derived thermogravimetry of the microparticles.

The first thermal event occurred between $28^{\circ} \mathrm{C}$ and $124{ }^{\circ} \mathrm{C}$ with $2.3 \%$ mass loss, which is related to free water loss $[28,29]$. Such water loss is evidenced through an endothermic peak at $59^{\circ} \mathrm{C}$ in the differential thermogravimetric curve (DTA). The second and main event occurred between $164.4^{\circ} \mathrm{C}$ and $357^{\circ} \mathrm{C}$, with an expressive mass loss (77.6\%) and indicated by an exothermic peak at $316{ }^{\circ} \mathrm{C}$ (DTA), which can be associated with fusion and degradation of the matrix polymeric material [30]. The third event occurred between $370{ }^{\circ} \mathrm{C}$ and $429{ }^{\circ} \mathrm{C}$ with $17 \%$ mass loss, confirmed by an exothermic peak at 
$411^{\circ} \mathrm{C}$ at differential thermogravimetric curve, and being attributable to the final decomposition of the microparticles [31]. Ballesteros et al. [32] studied the encapsulation of antioxidant phenolic compounds from spent coffee grounds by freeze-drying and spray-drying using maltodextrin, and a mixture of these components as coating materials, and observed similar peaks; an endothermic peak between $25^{\circ} \mathrm{C}$ and $180{ }^{\circ} \mathrm{C}$ related to water evaporation. A second mass loss event was observed between $190^{\circ} \mathrm{C}$ and $370^{\circ} \mathrm{C}$ (exothermic peak at around $300^{\circ} \mathrm{C}$ ), and could be related to depolymerization of the materials. The results of the thermal analysis demonstrated that the microparticles have high thermal stability, considering the usual temperature standards employed in the production processes of pharmaceutical and food industries.

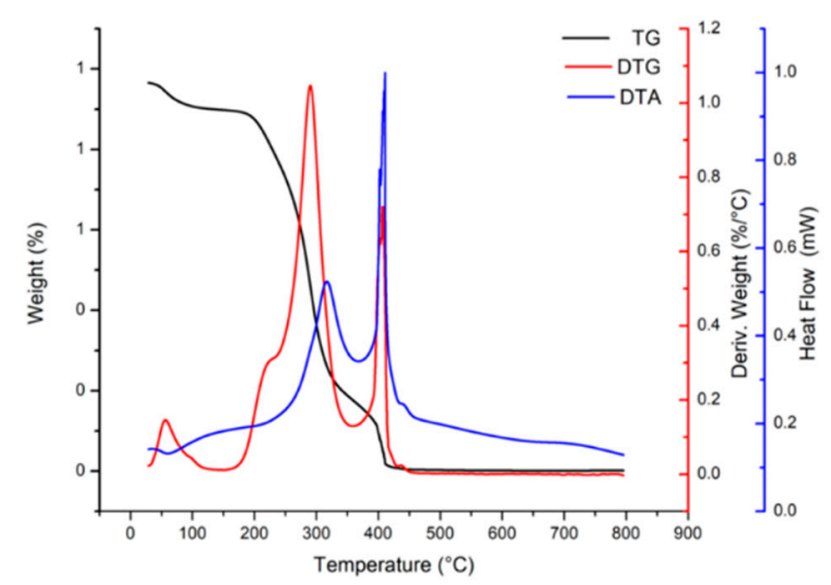

Figure 5. Thermogravimetric (TG) and derived thermogravimetric (DTG) profiles of microparticles.

X-ray diffraction analyses showed that the microparticles have an amorphous structure (Figure 6) indicated by a broad peak observed at approximately $19^{\circ}(2 \theta)$. Similarly, Ballesteros et al. [32] found a low degree of crystallinity in samples of phenolic compounds extracted from spent coffee grounds and encapsulated in maltodextrin and gum arabic. Such samples showed a diffractographic pattern characterized by a very broad peak at approximately $18^{\circ}(2 \theta)$, as also found in the present study. In fact, microparticles with amorphous structure were to be expected, considering the polymeric composition of the matrix materials (lasiodiplodan and gum arabic associated with maltodextrin). It is important to note that amorphous drug systems are widely used to improve the bioavailability and oral and aqueous solubility of a drug [33].

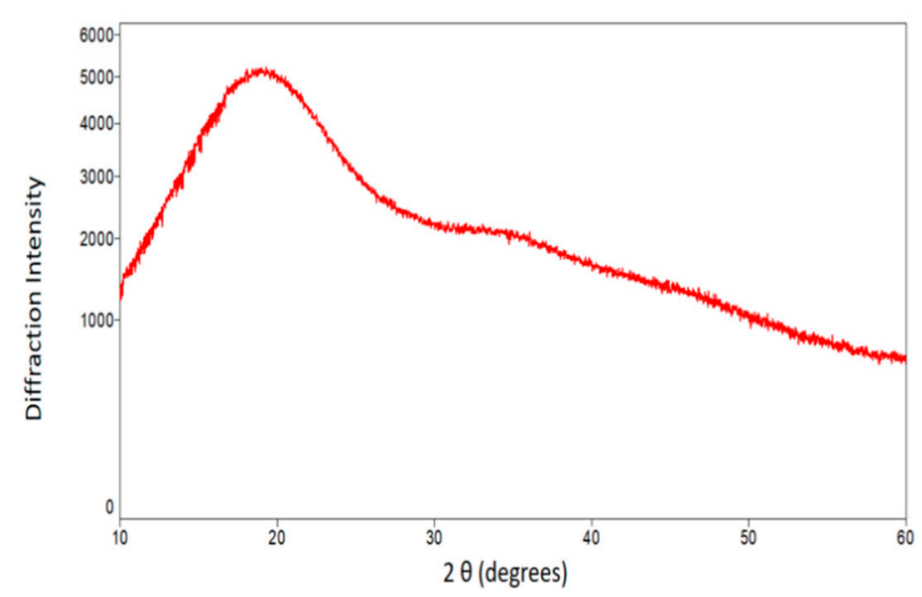

Figure 6. X-ray diffraction patterns of the microparticles. 


\subsection{FT-IR Spectroscopy}

Fourier-transform infrared (FT-IR) spectroscopy analysis was used to assess differences and similarities between the microparticles and the component materials constituting their matrices and the lyophilized extract (BDE) (Figure 7).
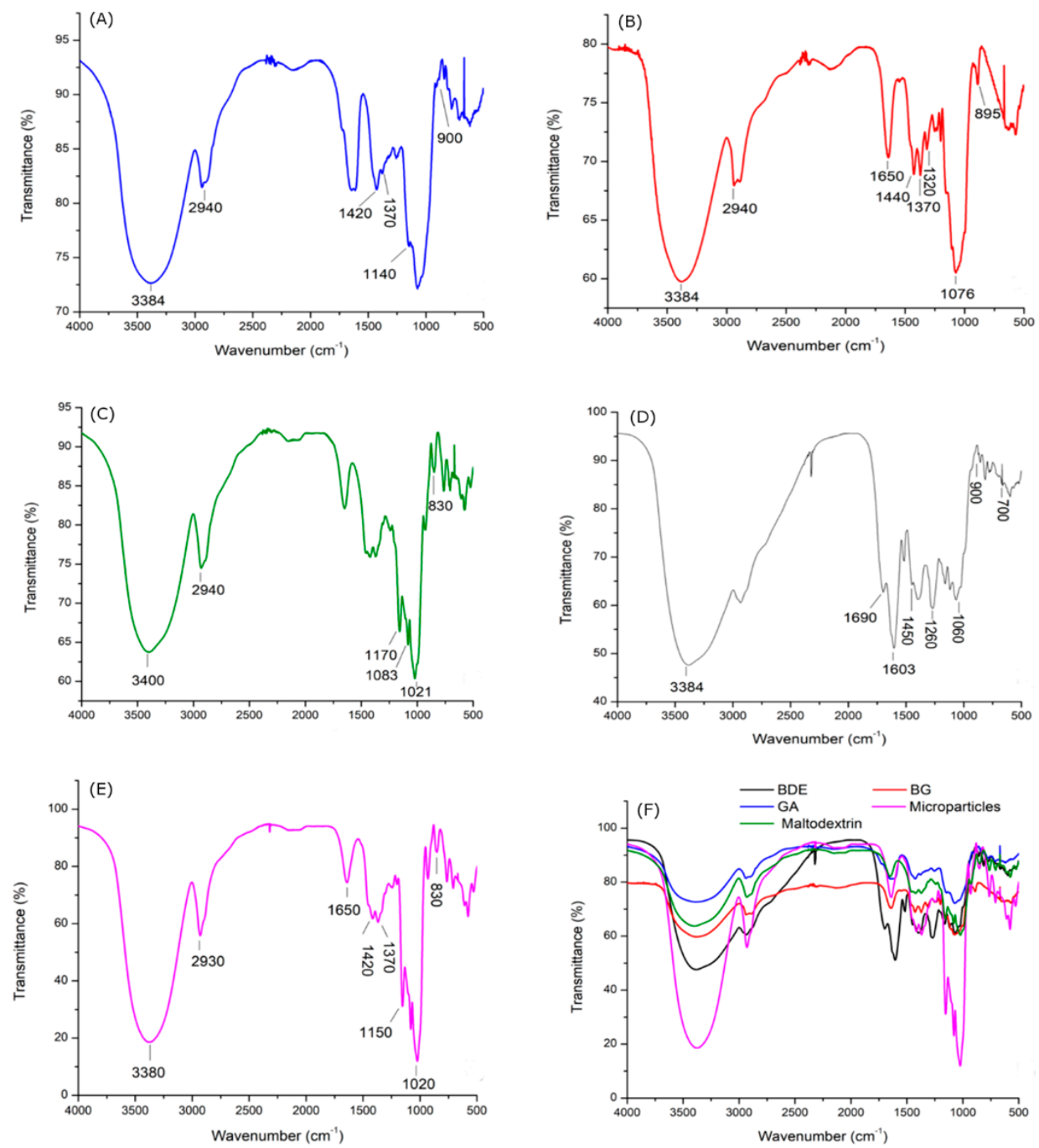

Figure 7. FT-IR spectra of gum arabic (A), $\beta$-glucan (B), maltodextrin (C), B. dracunculifolia extract (D); microparticles obtained in run $6(\mathbf{E})$, and overlapped spectra $(\mathbf{F})$.

The FT-IR spectra of maltodextrin, gum arabic and lasiodiplodan (Figure 7) showed bands characteristic of polysaccharides. Strong intensity bands in the region between $3000-3600 \mathrm{~cm}^{-1}$ corresponded to $-\mathrm{OH}$ stretching vibration [34,35]. Bands in the $2940 \mathrm{~cm}^{-1}$ region (Figure 7A-F) were attributed to the $\mathrm{C}-\mathrm{H}$ stretching vibration $[36,37]$. The band around $1400-1370 \mathrm{~cm}^{-1}$ in gum arabic (Figure 7A) was assigned to the $-\mathrm{OH}$ bending and $\mathrm{C}=\mathrm{O}$ symmetrical stretching of the carboxyl groups present in glucuronic acids, a constituent of the structure of gum arabic. Furthermore, a broad band was observed in the region between $900 \mathrm{~cm}^{-1}$ and $1140 \mathrm{~cm}^{-1}$ that is characteristic of gum arabic and is due to the $\mathrm{C}-\mathrm{O}$ stretching of arabinogalactans [38]. It is important to note that gum arabic is a complex macromolecule, which in addition to the polysaccharide constitution also contains small amounts of protein. However, specific signals characteristic of protein groups corresponding to the amino group were not observed in the FT-IR spectra of the gum arabic sample, and this could be due to overlapping signals with the hydroxyl group $(-\mathrm{OH})$ from the polysaccharide [34]. Band at $1320 \mathrm{~cm}^{-1}$ corresponding to $-\mathrm{OH}$ bending of the $\mathrm{C}-\mathrm{OH}$ group [39] was verified in the $(1 \rightarrow 6)-\beta-\mathrm{D}$-glucan sample (Figure $7 \mathrm{~B})$. 
The bands next to $1650 \mathrm{~cm}^{-1}$ (Figure 7A-E) refer to the glucose ring [31,40], and the bands observed around $1370-1450 \mathrm{~cm}^{-1}$ refer to the symmetrical deformation of $\mathrm{C}-\mathrm{OH}$ and $\mathrm{CH}_{2}$ groups [31]. The band observed at $1076 \mathrm{~cm}^{-1}$ (Figure $7 \mathrm{~B}$ ) is due to the symmetrical stretching vibrations of $\mathrm{C}-\mathrm{O}-\mathrm{C}$ bonds, characteristic of sugars, and the band at $1243 \mathrm{~cm}^{-1}$ is characteristic of asymmetric vibrations [31]. The band observed at $895 \mathrm{~cm}^{-1}$ was characteristic of a $\beta$-glucan [41].

Maltodextrin (Figure 7C) is a mixture of oligosaccharides composed of a chain of 5 to 10 glucose units per molecule and is derived by starch hydrolysis [42]. Maltodextrin presents bands at $1021 \mathrm{~cm}^{-1}$, $1083 \mathrm{~cm}^{-1}$, and $1158 \mathrm{~cm}^{-1}$, which are related to the $\mathrm{C}-\mathrm{O}$ stretching and $\mathrm{C}-\mathrm{OH}$ bending vibrations [43]. The bands observed between $800 \mathrm{~cm}^{-1}$ and $1200 \mathrm{~cm}^{-1}$ (see Figure 7C) are attributable to the $\mathrm{C}-\mathrm{O}$ bond stretching, a characteristic of the anhydroglucose ring [42].

The infrared spectrum of B. dracunculifolia extract (Figure 7d) was obtained with the purpose of comparison with the spectrum of the microparticles considering their complex composition, which includes flavonoids and phenolic acids [10]. Several absorption bands, including a wide band at $3384 \mathrm{~cm}^{-1}$ assigned to $-\mathrm{OH}$ stretching vibration from alcohols or phenolic compounds, bands at 1603 and $1450 \mathrm{~cm}^{-1}$ corresponding to $\mathrm{C}=\mathrm{C}$ axial deformation in aromatic compounds, and the band around $1690 \mathrm{~cm}^{-1}$ related to conjugated carbonyl or hydrogen bonding [44], were also observed.

According to Silva et al. [44], such bands are generally related to flavonoid compounds. Alcohols and phenols exhibit vibrational stretching with strong bands between $1260 \mathrm{~cm}^{-1}$ and $1000 \mathrm{~cm}^{-1}$ [45]. In the $900-700 \mathrm{~cm}^{-1}$ region, the bands observed are related to $\mathrm{CH}$ angular deformations in aromatic groups [45].

\subsection{Kinetics of the Release of B. dracunculifolia Extract from the Microparticles}

The sample produced in run 6 (Table 1), which presented the highest concentrations of total phenolics, was characterized for the release of B. dracunculifolia extract, and the release profile into the medium was examined as a function of time and $\mathrm{pH}$ (Figure 8). A fast release of BDE was observed to occur at the beginning of the assay profile and was followed by a sustained release; a biphasic release characteristic [46], and appeared to be influenced by $\mathrm{pH}$ of the medium (Figure 8A,B). Over the first $10 \mathrm{~h}$, the release of the extract was more pronounced, but thereafter a reduction in the release rate followed by a sustained release occurred.
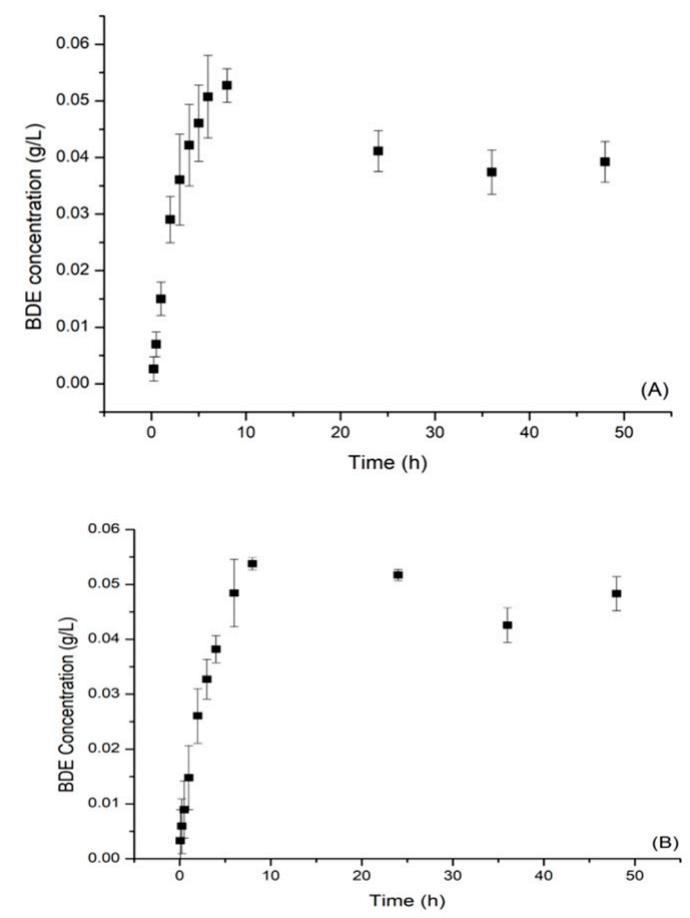

Figure 8. B. dracunculifolia extract release kinetic curves at pH 2.6 (A) and pH 7.7 (B). 
Several mechanisms can control the release of drugs, such as diffusion, erosion, or osmosis, and several mathematical models have been proposed and can be used to explain the release profile [47]. These models were developed to try to elucidate the swelling and release kinetic processes of the polymer particles, among the models were first order [48], and those proposed by Korsmeyer et al. [49] and by Siepman and Peppas [50], which have been reported in several studies [51,52]. The release kinetic studies provide information for the interpretation of the relationship between the structure of the studied materials and the transport mechanism involved, and it is fundamental to relate transport at the molecular level with the macroscopic information [53].

According to Rigter and Peppas [54], the shape and size distribution of the microparticles significantly influence the release kinetics so that the values for the kinetic constant cannot be limited. The kinetic data were adjusted to mathematical models of first order, Korsmeyer and Peppas, and Higuchi as shown in Table 3.

Table 3. Models of the release kinetics of B. dracunculifolia extract.

\begin{tabular}{ccc}
\hline \multirow{2}{*}{ Phenolics Release Models } & \multicolumn{2}{c}{$\mathbf{p H}$ of the Medium } \\
\cline { 2 - 3 } & $\mathbf{2 . 6 1}$ & $\mathbf{7 . 7 0}$ \\
\hline \multirow{3}{*}{ First order } & $\mathrm{R}^{2}=0.96$ & $\mathrm{R}^{2}=0.96$ \\
& $\mathrm{~K}=0.4959\left(\mathrm{~h}^{-1}\right)$ & $\mathrm{K}=0.4231\left(\mathrm{~h}^{-1}\right)$ \\
& $\mathrm{y}=-0.4959 \mathrm{x}-2.7853$ & $\mathrm{y}=-0.4231 \mathrm{x}-2.8863$ \\
\hline \multirow{2}{*}{ Korsmeyer-Peppas } & $\mathrm{R}^{2}=0.99$ & $\mathrm{R}^{2}=0.99$ \\
& $\mathrm{~K}=0.27$ & $\mathrm{~K}=0.29$ \\
& $\mathrm{n}=1.15$ & $\mathrm{n}=0.64$ \\
& $\mathrm{y}=1.1517 \mathrm{x}-1.3199$ & $\mathrm{y}=0.6457 \mathrm{x}-1.2211$ \\
\hline \multirow{2}{*}{ Higuchi } & $\mathrm{R}^{2}=0.99$ & $\mathrm{R}^{2}=0.96$ \\
& $\mathrm{~K}=0.4743$ & $\mathrm{~K}=0.15$ \\
& $\mathrm{y}=0.4743 \mathrm{x}-0.169$ & $\mathrm{y}=0.1498 \mathrm{x}+0.1161$ \\
\hline
\end{tabular}

$\mathrm{R}^{2}$ : correlation coefficient; $\mathrm{K}$ : constant kinetics of $B$. dracunculifolia bioactive release; $\mathrm{n}$ : diffusional exponent; $\mathrm{x}$ : linear coefficient of the model.

The models that better represented the release profile of the BDE from the microparticles were those of Korsmeyer and Peppas, and Higuchi, as shown in Table 3, through the $\left(\mathrm{R}^{2}\right)$ correlation coefficients. By the Korsmeyer and Peppas model, which demonstrated the best fit of the data, diffusional exponent (n) values of $0.64(\mathrm{pH} 7.70)$ and 1.15 (pH 2.61) were found. The diffusional exponent $(\mathrm{n})$ values vary according to the system geometry of the particles, with values of $n=0.43$ for a sphere, $n=0.45$ for a cylinder, and $\mathrm{n}=0.5$ for a thin film with Fickian diffusion [55,56]. Diffusional exponent (n) values of 0.89 indicate a Case II transport, and values greater than 0.89 characterize Super Case II transport [57], which is controlled by diffusion, polymer chain relaxation, and erosion [58]. In this model, the " $\mathrm{K}$ " constant is considered the release velocity and reflects the geometrical structural characteristics of the system [59]. As observed in Table 3, conditions of acid $\mathrm{pH}$ contributed to a release mechanism of the type Super Case II $(\mathrm{n}=1.15)$, which is related to polymer relaxation and erosion. Conversely, under conditions close to neutrality ( $\mathrm{pH}$ 7.70), a release mechanism of the type non-Fickian or anomalous $(\mathrm{n}=0.64)$ was observed.

\subsection{Scanning Electron Microscopy—SEM}

SEM micrographs revealed particles (Figure 9) with irregular and rough surfaces similar to raisins, and did not present uniform dimensions (diameter). Such features are associated with the possible incorporation of air inside the particles that occur during the atomization process [60]. Commonly, particles obtained by spray-drying present in the form of hollow spheres. The formation of vacuoles is a consequence of the expanding air bubbles trapped within the droplet, and is accompanied by the shrinkage of the coated material on the particle, which occurs as a function of drying the particle [61]. The thermal expansion of air or steam inside the drying particles is associated with the drying rate and 
the viscoelastic properties of the matrix [62]. Uniform spherical particles are most commonly obtained when more viscoelastic material is employed as the coating matrix [61]. The elasticity of the matrix during the drying process promotes greater homogeneity and uniformity of the particle wall.

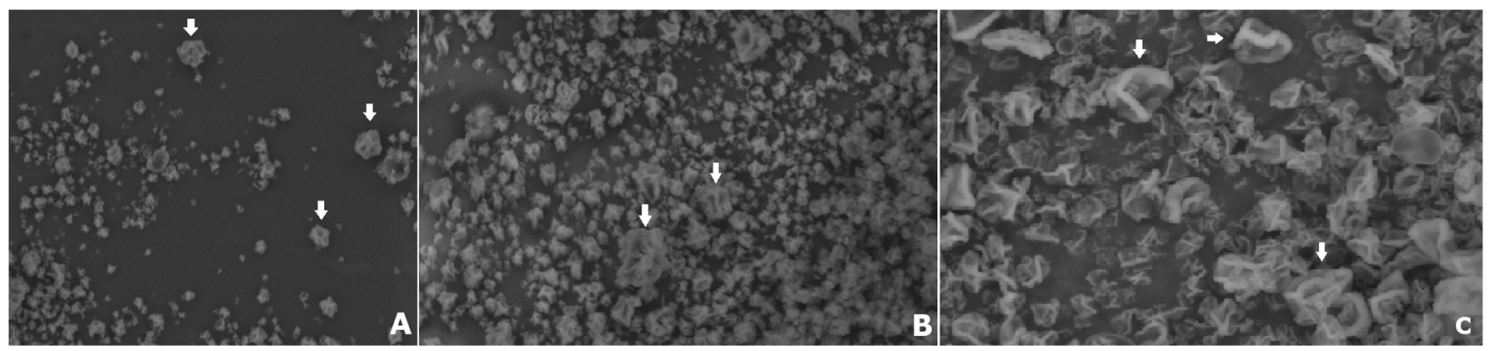

Figure 9. SEM micrographs at magnification of 1500X (A,B) and 3000X (C). Arrows indicating particles similar to raisins.

\subsection{Chromatographic Profile of the Encapsulated Phenolic Compounds}

The microparticles were analyzed by HPLC-DAD after extraction and subjected to two different analysis protocols. Protocol 1 was developed for the detection and analysis of phenolic acids, while protocol 2 detected flavonoids (Figure 10 and Table 4). A major component observed was identified as caffeic acid $(17.16 \mathrm{mg} / \mathrm{L})$ followed by p-coumaric acid $(16.86 \mathrm{mg} / \mathrm{L})$. These compounds were also identified in the work of Rezende et al. [63] and Sousa et al. [64] in B. dracunculifolia extract. Catechin $(6.06 \mathrm{mg} / \mathrm{L})$ is commonly found in species of the genus Baccharis; e.g., B. uncinella, B. dentata, and B. anomala [65]. The presence of these bioactive compounds identified by HPLC analysis indicate the resistance of the microparticles to the temperature conditions employed in the atomization process during spray-drying.
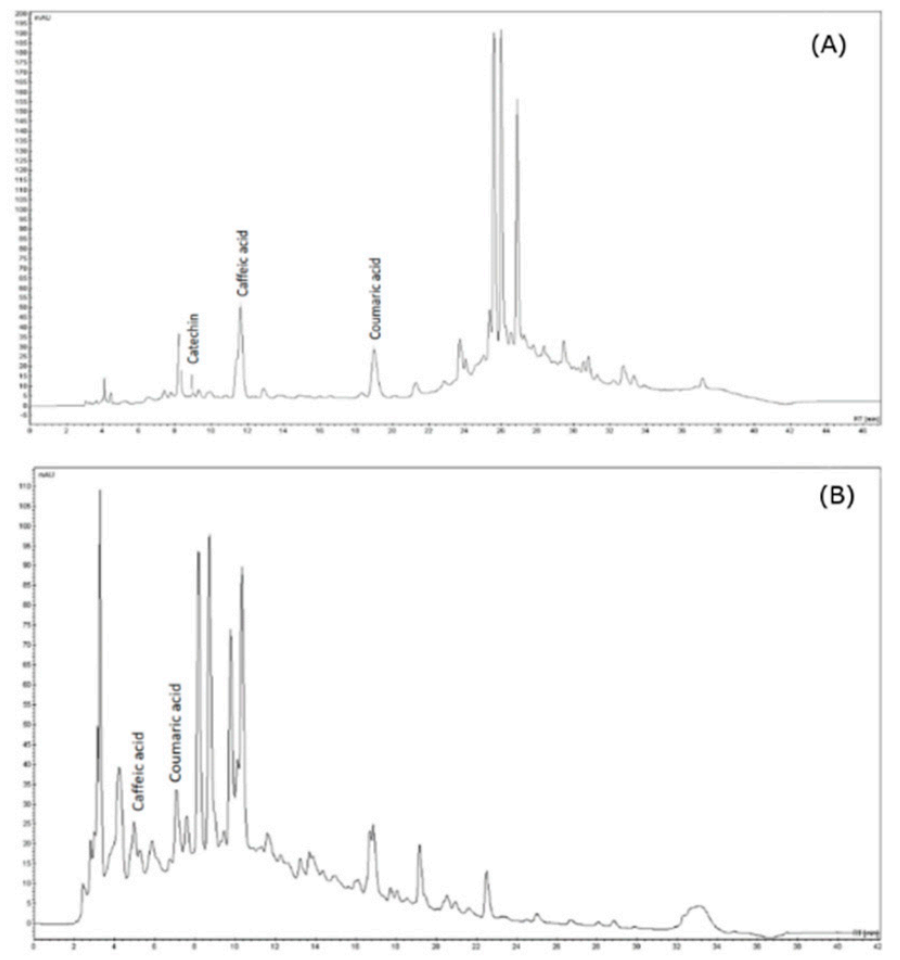

Figure 10. Representative HPLC chromatograms of phenolic compounds extracted from microcapsules and measured in a UV detector at $280 \mathrm{~nm}$ (catechin), $300 \mathrm{~nm}$ (coumaric acid) and $320 \mathrm{~nm}$ (caffeic acid). (A) protocol 1 and (B) protocol 2. 
Table 4. Chromatographic parameters of the phenolic compounds analyzed by HPLC-DAD.

\begin{tabular}{lccccc}
\hline \multicolumn{1}{c}{ Standard } & RT (min) & $\kappa_{\text {max }}(\mathbf{n m})$ & Regression Equation & $\mathbf{R}^{\mathbf{2}}$ Value & $\begin{array}{c}\text { Concentration } \\
(\mathbf{m g} / \mathbf{L})\end{array}$ \\
\hline $\begin{array}{l}\text { Protocol 1 } \\
\begin{array}{l}\text { Catechin } \\
\text { Protocol 2 }\end{array}\end{array}$ & 8.96 & 276 & $\mathrm{Y}=0.1794 \mathrm{x}-0.156$ & 0.9945 & 6.06 \\
$\begin{array}{l}\text { Caffeic acid } \\
p \text {-Coumaric acid }\end{array}$ & 11.57 & 320 & $\mathrm{Y}=1.0138 \mathrm{x}-1.229$ & 0.9836 & 17.16 \\
\hline
\end{tabular}

Data are presented as mean $\pm S E M ; n=3$; RT: retention time; $R^{2}$ : coefficient of determination (R-squared).

\section{Materials and Methods}

\subsection{Botanical Material and Reagents}

B. dracunculifolia grown on the campus of Universidade Estadual do Centro-Oeste Paraná, at Guarapuava, Paraná Brazil; coordinates: 1.120 m altitude, 50 $39^{\prime} 42.39^{\prime \prime}$ West Longitude and $25^{\circ} 32^{\prime} 7.24^{\prime \prime}$ South Latitude), was collected in November 2017. The voucher specimen was deposited in the Herbarium of Universidade Estadual de Ponta Grossa, Ponta Grossa, Paraná Brazil, and registered under the number 18173.

Folin-Ciocalteu reagent, 1,1-diphenyl-2-picrylhydrazyl (DPPH), methanol, potassium persulfate, gallic acid, 6-hydroxyl-2,5,7,8-tetramethylchroman-2-carboxylic acid (Trolox), 2,2'-azino-bis (3-ethylbenzothiazoline-6-sulfonic acid) (ABTS), and gum arabic were obtained from Sigma-Aldrich (St Louis, MO, USA). Maltodextrin (Mor-rex 1910-10 DE, food grade) was kindly provided by Plury Química (Diadema, SP, Brazil). Lasiodiplodan, $\left((1 \rightarrow 6)-\beta\right.$-D-glucan of MW $\left.1.4 \times 10^{6} \mathrm{Da}\right)$ was produced by submerged fermentation on liquid medium containing glucose $(20 \mathrm{~g} / \mathrm{L})$ as carbon source in (shake flasks), and isolated from the fermentation broth by precipitation with ethanol as described by Cunha et al. [66]. All reagents used in this study were of analytical grade.

\subsection{Production of B. dracunculifolia Extract}

An extract of B. dracunculifolia was produced according to the conditions optimized in a previous study. The bioactive compounds present in dehydrated leaves of the plant were ground and extracted with methanol, (1:4 ratio of mass of plant material to volume of $95 \%$ methanol) in an orbital incubator (TE-4200, Tecnal, Piracicaba, São Paulo, Brazil) for $20 \mathrm{~min}$ at $70^{\circ} \mathrm{C}$. Solvent from the plant extract was removed under vacuum by rotary evaporation (TE-210, Tecnal, Piracicaba, São Paulo, Brazil) at $45^{\circ} \mathrm{C}$. The material extract was frozen at $-50^{\circ} \mathrm{C}$, and then lyophilized.

\subsection{Production of Encapsulated Microparticles by Factorial Design Matrix}

Microparticles were produced according to Salgado et al. [67] with adaptations. Gum arabic and lasiodiplodan were separately dissolved in water at $60^{\circ} \mathrm{C}$ by stirring ( $350 \mathrm{rpm}$ ) for $20 \mathrm{~min}$ and $24 \mathrm{~h}$, respectively. Maltodextrin was dissolved in water at room temperature and stirred for $20 \mathrm{~min}$. Then the solutions $(100 \mathrm{~mL})$ of gum arabic and lasiodiplodan solutions were mixed with the maltodextrin solution $(200 \mathrm{~mL})$ at high speed in a Ultraturrax homogenizer (Ika, Staufen, Germany) at 20,000 rpm for $20 \mathrm{~min}$ [67]. The lyophilized extract of B. dracunculifolia was next dispersed in the above solution at $12,000 \mathrm{rpm}$ agitation, and the solution was spray-dried using a Buchi Mini Spray Dryer B-290 (Flawil, Switzerland) employing a feed flow of $83 \mathrm{~L} / \mathrm{h}$ at a compressed air pressure of 0.55 bar. The drying conditions were set at $130^{\circ} \mathrm{C}$ inlet and $87^{\circ} \mathrm{C}$ outlet [68]. The microparticles were collected and placed in amber glass bottles for further characterization analyses.

The concentrations of gum arabic, $\beta$-glucan (lasiodiplodan), and the lyophilized extract (BDE) varied according to the $2^{3}$ full factorial design as described in Table 1 . Maltodextrin concentration was maintained at $10 \%(w / v)$ in all experimental runs. 


\subsection{Determination of Total Phenolic Content and Antioxidant Activity}

The microparticle samples were extracted according to protocol described by Saikia et al. [69] with some modifications. Samples of $500 \mathrm{mg}$ of microparticles were accurately weighed and dispersed in $5 \mathrm{~mL}$ of a mixture containing absolute ethanol, glacial acetic acid, and distilled water (50:8:42). The tubes were vortexed for $1 \mathrm{~min}$, and the samples filtered through $0.45 \mu \mathrm{m}$ Millipore membrane (Merck $\mathrm{KGaA}$, Darmstadt, Germany). The filtrates were used in the analysis of the total phenolics content and antioxidant activity.

\subsubsection{Total Phenolics Content in the Microparticles}

The total phenolics content was determined by Folin-Ciocalteu method as described by Singleton and Rossi [70]. Volumes of $2.5 \mathrm{~mL}$ of Folin-Ciocalteu reagent solution $(10 \%, v / v), 0.5 \mathrm{~mL}$ of microparticle filtrate, and $2 \mathrm{~mL}$ of sodium carbonate solution $(4 \% w / v)$ were mixed in a test tubes, and kept at room temperature in the dark for $2 \mathrm{~h}$. Absorbance was read at $750 \mathrm{~nm}$ in a UV/VIS Digilab-Hitachi U-2800 Spectrophotometer (Lambda Advanced Technology, Wembley, UK). In the blank tube, the filtrate from microparticles was replaced by $0.5 \mathrm{~mL}$ of distilled water. Gallic acid was employed as a standard, using a calibration curve within the concentration range of $0-100 \mathrm{mg}\left(R^{2}=0.9996\right)$, and the results were expressed as gallic acid equivalents ( $\mu \mathrm{g} \mathrm{GAE} / \mathrm{g}$ microparticles).

\subsubsection{DPPH Free Radical Scavenging Activity}

The 1,1-diphenyl-2-picrylhydrazyl (DPPH) scavenging activity of microparticles was evaluated according to Brand-Williams et al. [71]. Aliquots of $0.5 \mathrm{~mL}$ of filtrate from the microparticles, $0.3 \mathrm{~mL}$ $\mathrm{DPPH}$ and $3 \mathrm{~mL}$ methanol were homogenized in test tubes, and then kept in the dark at room temperature for $60 \mathrm{~min}$. Methanol was used as the blank. Control sample contained a mixture of $0.3 \mathrm{~mL}$ of DPPH radical solution and 3.5 methanol. Trolox was used as the reference antioxidant standard, and the results were expressed in $\mu \mathrm{mol} / \mathrm{L}$ Trolox equivalent/g of microparticles calculated from a calibration curve (15-150 $\mu \mathrm{mol}$ Trolox/L, $\left.\mathrm{R}^{2}=0.996\right)$.

\subsubsection{ABTS Free Radical Scavenging Activity}

The ABTS cation free radical scavenging capacity was determined according to Huang et al. [72]. ABTS cation radical was generated by mixing $5 \mathrm{~mL}$ of ABTS solution $(7 \mathrm{mmol} / \mathrm{L})$ and $88 \mu \mathrm{L}$ of potassium persulfate solution $(2.45 \mathrm{mmol} / \mathrm{L})$ in test tubes, which were then left in the dark at room temperature for $16 \mathrm{~h}$. An aliquot of $3 \mathrm{~mL}$ of this solution was diluted with methanol until absorbance 0.700 at $734 \mathrm{~nm}$, and then $3 \mathrm{~mL}$ this solution was mixed with $30 \mu \mathrm{L}$ of filtrate from the microparticles followed by homogenization, and the homogenate kept in the dark for $6 \mathrm{~min}$. Methanol was used as a blank. Trolox antioxidant standard $\left(100-2000 \mu \mathrm{mol} / \mathrm{L}, \mathrm{R}^{2}=0.998\right)$ calibration curve was used to determine the results, expressed as Trolox equivalent $\mu \mathrm{mol} / \mathrm{L}$ per $\mathrm{g}$ of microcapsules.

\subsubsection{Ferric Reducing Antioxidant Power (FRAP) Assay}

The ferric reducing antioxidant power (FRAP) was determined according to Wootton-Beard and Ryan [73]. An aliquot filtrate $(90 \mu \mathrm{L})$ was mixed with $2700 \mu \mathrm{L}$ of FRAP solution and $270 \mu \mathrm{L}$ of distilled water. This solution was homogenized in a test tube and kept in the dark for $30 \mathrm{~min}$ at $37^{\circ} \mathrm{C}$. FRAP reagent was used as the blank. The results were determined from a calibration curve of ferrous sulfate $\left(5-50 \mu \mathrm{mol} / \mathrm{L}, \mathrm{R}^{2}=0.992\right)$. Absorbance was measured at $595 \mathrm{~nm}$, and the $\mathrm{Fe}^{+3}$ to $\mathrm{Fe}^{+2}$ reducing power was expressed as $\mu \mathrm{mol} \mathrm{FeSO}_{4} \cdot 7 \mathrm{H}_{2} \mathrm{O}$ per g of microparticles.

\subsection{Kinetics of the Release of B. dracunculifolia Extract from the Microparticles}

The release kinetics of the plant extract from the microparticles was evaluated by measuring the extract content released into the medium (buffer solutions) over the contact time. A sample of $350 \mathrm{mg}$ of microparticles were dispersed in $10 \mathrm{~mL}$ of buffer solution $\mathrm{pH} 2.6$ or $\mathrm{pH} 7.5$ (pH 2.6: sodium 
acetate buffer; pH 7.6: sodium phosphate buffer-PBS). The microparticles dispersed in the buffer solutions were immersed in $150 \mathrm{~mL}$ of the respective buffer, and were submitted to dialysis in cellulose membranes (12,000 Da, 1.3 in diam., Sigma-Aldrich).

At predetermined intervals $(5 \mathrm{~min}, 15 \mathrm{~min}, 30 \mathrm{~min}, 1 \mathrm{~h}, 2 \mathrm{~h}, 3 \mathrm{~h}, 4 \mathrm{~h}, 6 \mathrm{~h}, 8 \mathrm{~h}, 24 \mathrm{~h}, 36 \mathrm{~h}$, and $48 \mathrm{~h}$ ), aliquots of $3 \mathrm{~mL}$ were removed from the solution for analysis, and the same volume of dissolution medium was restored to solution to maintain the sink condition to avoid the decrease of the intrinsic dissolution rate caused by the saturation proximity [74]. The mass of the lyophilized extract released was analyzed on a UV/VIS Digilab-Hitachi U-2800 Spectrophotometer (Lambda Advanced Technology) with reading at $315 \mathrm{~nm}$, and correlation with a B. dracunculifolia solution calibration curve $\left(0.0975\right.$ to $\left.90 \mathrm{mg} / \mathrm{L}, \mathrm{R}^{2}=0.99\right)$. To characterize the release mechanism, the kinetic parameters were determined using the models: first order [48], Korsmeyer-Peppas [49] and Higuchi [50].

\subsection{HPLC-DAD Analysis}

The profile of phenolic compounds released from the microcapsules was analyzed on a Varian 920 LC HPLC system (Varian Inc., Walnut Creek, CA, USA) coupled to photodiode array detector (DAD), and using a reverse-phase C-18 RP $(250 \times 4.6 \mathrm{~mm} \times 5 \mu \mathrm{m})$ column (Microsorb MV-100, Agilent Technologies, Wilmington, DE, USA). The injection volume was $10 \mu \mathrm{L}$ at a concentration $7.54 \mathrm{mg} / \mathrm{mL}$ and the column was kept at $30^{\circ} \mathrm{C}$.

In order to identify a higher number of bioactive compounds, two protocols of analysis were used:

Protocol 1: A gradient mode system was used to elute the samples from the HPLC column at a flow rate of $1 \mathrm{~mL} / \mathrm{min}$. Solvent A: acidified water with acetic acid $(2 \%, v / v)$. Solvent B: acetonitrile: water: acetic acid at 58:40:2 (v/v). The solvent gradient mixtures were: mobile phase A $95 \%$ and B 5\% ( $2 \mathrm{~min}) ; \mathrm{A} 80 \%$ and B 20\% (13 $\mathrm{min}) ; \mathrm{A} 75 \%$ and B 5\% (10 min); A 5\% and B 85\% (7 min); A 5\% and B 95\% (4 min); A 95\% and B 5\% (9 min).

Protocol 2: The mobile phase consisted of a mixture of solvents A (water) and B (acidified methanol with o-phosphoric acid) using a flow rate of $1 \mathrm{~mL} / \mathrm{min}$. The solvent gradient mixtures used were: mobile phase A 70\% and B 30\% (15 min); A 36\% and B 64\% (26 min); A 25\% and B 75\% (28 min); A 5\% and B $95 \%$ (32 min); and to B 70\% and A 30\%.

The peak areas were determined by reading the absorbance at $280 \mathrm{~nm}$ for the catechin, $300 \mathrm{~nm}$ for coumaric acid, and $320 \mathrm{~nm}$ for caffeic acid.

\subsection{Infrared Spectroscopy Analysis (FT-IR)}

The microcapsules were ground and mixed with spectroscopic grade potassium bromide. The mixture was pressed ( $7 \mathrm{Kgf}$ for $7 \mathrm{~min}$ ) to result in a compact and clear disc, and was analyzed in the FT-IR Spectrophotometer Frontier (Perkin Elmer, Shelton, CT, USA) in the region of $4000-400 \mathrm{~cm}^{-1}$, with a resolution of $4 \mathrm{~cm}^{-1}$ and 32 accumulated scans.

\subsection{X-ray Diffraction Analysis}

X-ray diffractogram patterns were recorded on a MiniFlex600 diffractometer (Rigaku, Tokyo, Japan) using copper radiation font $(\mathrm{CuK} \alpha=1.5418 \AA), 30 \mathrm{~mA}$ current, $40 \mathrm{kV}$ voltage, scanning range of $10^{\circ}$ to $60^{\circ}(2 \theta), 0.02^{\circ}$ step at $2 \theta$, and a scanning speed of $0.5^{\circ} /$ minute speed.

\subsection{Scanning Electron Microscopy (SEM)}

Micrographs were obtained in a scanning electron microscope (Hitachi TM3000, Irving, TX, USA). The microcapsules were fixed in a holder with carbon tapes, and images were taken at magnifications of $1000 \times$ and $1500 \times$. 


\subsection{Thermal Analysis}

The microcapsules were submitted to thermogravimetry, differential thermal analysis, and thermogravimetric analysis between $25^{\circ} \mathrm{C}$ and $800^{\circ} \mathrm{C}$, in a synthetic air atmosphere, with a flow rate of $50 \mathrm{~mL} / \mathrm{min}$ and a heating rate of $10^{\circ} \mathrm{C} /$ minute in a SDT Q600 thermal analyzer equipment (TA Instruments, New Castle, DE, USA).

\subsection{Microparticles Size Measurement and Zeta Potential}

The particle size distribution and ZP were evaluated in a Zetasizer Nano, ZS90 instrument (Malvern, UK). Samples were diluted in $0.1 \mathrm{~mol} / \mathrm{L} \mathrm{KCl}$ at a concentration of approximately $0.025 \%(v / v)$.

\section{Conclusions}

Microparticles containing $(1 \rightarrow 6)-\beta$-D-glucan (lasiodiplodan) and B. dracunculifolia extract were produced by a spray-drying method. The microparticles presented high phenolic contents and antioxidant potential, when formulated with maltodextrin $(10 \%, w / v)$ as a matrix material along with lasiodiplodan $(1.5 \%(w / v)$ and a lyophilized extract of $B$. dracunculifolia leaves $(5.0 \%, w / v)$. The high antioxidant activity of the microparticles indicate that spray-drying process, even conducted at relatively high temperatures, bore no negative influence either on the total phenolic content or on the antioxidant activity. The microparticles ranged in size from $0.24-1.21 \mu \mathrm{m}$; a range considered adequate for the methodology used. The polydispersity index of the microparticles was high, which may be related to the high viscosity of the solution of lasiodiplodan. In this study, the model that best represented the release profile kinetics was the Korsmeyer and Peppas model. The diffusional exponent (n) values in neutral $\mathrm{pH}$ dissolution medium of 0.64 displayed a non-Fickian or anomalous transport system, while that of 1.15 indicated a Super Case II transport phenomenon. High-performance liquid chromatography using acidified water and acetonitrile: water: acetic acid as eluents in a gradient system allowed the separation and identification of three phenolic compounds-catechin $(6.06 \mathrm{mg} / \mathrm{L})$, caffeic acid $(17.16 \mathrm{mg} / \mathrm{L})$, and p-coumaric acid $(16.86 \mathrm{mg} / \mathrm{L})$-in the microparticles. The microparticles obtained constitute a new biomaterial that in addition to containing microbial $\beta$-glucan, a known immunomodulatory biomacromolecule, was rich in phenolics compounds and presented high antioxidant potential.

Author Contributions: Conceptualization: G.I.; methodology: G.I., D.D. and V.A.Q.S.; formal analysis: G.I., D.D. and V.A.Q.S.; investigation; writing—original draft preparation: G.I., C.R.M.M. and M.A.A.d.C.; writing-review and editing: R.F.H.D. Collaborative efforts: A.M.B.-D., R.F.H.D. and V.V.

Funding: The authors thank the Brazilian agencies for financial support: Conselho Nacional de Desenvolvimento Científico e Tecnológico (CNPq), Coordenação de Aperfeiçoamento de Pessoal de Nível Superior (CAPES), and Fundação Araucária (M.A.A. Cunha).

Conflicts of Interest: The authors declare no conflict of interest. The funders had no role in the design of the study; in the collection, analyses, or interpretation of data; in the writing of the manuscript, or in the decision to publish the results.

\section{References}

1. Pan, S.-Y.; Zhou, S.-F.; Gao, S.-H.; Yu, Z.-L.; Zhang, S.-F.; Tang, M.-K.; Sun, J.-N.; Ma, D.-L.; Han, Y.-F.; Fong, W.-F.; et al. New Perspectives on how to discover drugs from herbal medicines: CAM's outstanding contribution to modern therapeutics. Evid. Based. Complement. Alternat. Med. 2013, 2013, 627375. [CrossRef] [PubMed]

2. Teixeira, C.C.C.; de Freitas Cabral, T.P.; Tacon, L.A.; Villardi, I.L.; Lanchote, A.D.; de Freitas, L.A.P. Solid state stability of polyphenols from a plant extract after fluid bed atmospheric spray-freeze-drying. Powder Technol. 2017, 319, 494-504. [CrossRef]

3. Gallo, L.; Piña, J.; Bucalá, V.; Allemandi, D.; Ramírez-Rigo, M.V. Development of a modified-release hydrophilic matrix system of a plant extract based on co-spray-dried powders. Powder Technol. 2013, 241, 252-262. [CrossRef] 
4. Singh, M.N.; Hemant, K.S.Y.; Ram, M.; Shivakumar, H.G. Microencapsulation: A promising technique for controlled drug delivery. Res. Pharm. Sci. 2010, 5, 65-77. [PubMed]

5. Cestari, S.H.; Bastos K., J.; Di Stasi, L.C. Intestinal anti-inflammatory activity of Baccharis dracunculifolia in the trinitrobenzenesulphonic acid model of rat colitis. Evid.-Based Complement. Altern. Med. 2011, 2011, 1-9. [CrossRef] [PubMed]

6. $\quad$ Figueiredo-Rinhel, A.S.G.; Kabeya, L.M.; Bueno, P.C.P.; Jorge-Tiossi, R.F.; Azzolini, A.E.C.S.; Bastos, J.K.; Lucisano-Valim, Y.M. Inhibition of the human neutrophil oxidative metabolism by Baccharis dracunculifolia DC (Asteraceae) is influenced by seasonality and the ratio of caffeic acid to other phenolic compounds. J. Ethnopharmacol. 2013, 150, 655-664. [CrossRef] [PubMed]

7. Dos Santos, D.A.; Fukui, M.J.; Dhammika, N.N.P.; Khan, S.I.; Sousa, J.P.B.; Bastos, J.K.; Andrade, S.F.; Da Silva, A.A.F.; Quintão, N.L.M. Anti-inflammatory and antinociceptive effects of Baccharis dracunculifolia DC (Asteraceae) in different experimental models. J. Ethnopharmacol. 2010, 127, 543-550. [CrossRef] [PubMed]

8. Hocayen, P.D.A.; Grassiolli, S.; Leite, N.C.; Pochapski, M.T.; Pereira, R.A.; da Silva, L.A.; Snack, A.L.; Michel, R.G.; Kagimura, F.Y.; da Cunha, M.A.; et al. Baccharis dracunculifolia methanol extract enhances glucose-stimulated insulin secretion in pancreatic islets of monosodium glutamate induced-obesity model rats. Pharm. Biol. 2016, 54, 1263-1271. [CrossRef]

9. Pereira, C.A.; Costa, A.C.B.P.; Liporoni, P.C.S.; Rego, M.A.; Jorge, A.O.C. Antibacterial activity of Baccharis dracunculifolia in planktonic cultures and biofilms of Streptococcus mutans. J. Infect. Public Health 2016, 9, 324-330. [CrossRef]

10. Guimarães, N.S.S.; Mello, J.C.; Paiva, J.S.; Bueno, P.C.P.; Berretta, A.A.; Torquato, R.J.; Nantes, I.L.; Rodrigues, T. Baccharis dracunculifolia, the main source of green propolis, exhibits potent antioxidant activity and prevents oxidative mitochondrial damage. Food Chem. Toxicol. 2012, 50, 1091-1097. [CrossRef]

11. Kagimura, F.Y.; da Cunha, M.A.A.; Barbosa, A.M.; Dekker, R.F.H.; Malfatti, C.R.M. Biological activities of derivatized d-glucans: A review. Int. J. Biol. Macromol. 2015, 72, 588-598. [CrossRef] [PubMed]

12. Magnani, M.; Castro-Gómez, R.J.H. $\beta$-glucana de Saccharomyces cerevisiae: Constituição, bioatividade e obtenção. Semin. Ciências Agrárias 2008, 29, 631-650. [CrossRef]

13. Vetvicka, V. Glucan-immunostimulant, adjuvant, potential drug. World J. Clin. Oncol. 2011, 2, 115-119. [CrossRef] [PubMed]

14. Ajazuddin; Saraf, S. Applications of novel drug delivery system for herbal formulations. Fitoterapia 2010, 81, 680-689. [CrossRef]

15. Ye, Q.; Woo, M.W.; Selomulya, C. Modification of molecular conformation of spray-dried whey protein microparticles improving digestibility and release characteristics. Food Chem. 2019, 280, 255-261. [CrossRef] [PubMed]

16. Walz, M.; Hirth, T.; Weber, A. Investigation of chemically modified inulin as encapsulation material for pharmaceutical substances by spray-drying. Colloids Surf. A Physicochem. Eng. Asp. 2018, 536, 47-52. [CrossRef]

17. Li, X.; Anton, N.; Arpagaus, C.; Belleteix, F.; Vandamme, T.F. Nanoparticles by spray drying using innovative new technology: The Büchi Nano Spray Dryer B-90. J. Control. Release 2010, 147, 304-310. [CrossRef] [PubMed]

18. Schuck, P.; Dolivet, A.; Méjean, S.; Zhu, P.; Blanchard, E.; Jeantet, R. Drying by desorption: A tool to determine spray drying parameters. J. Food Eng. 2009, 94, 199-204. [CrossRef]

19. Haque, M.A.; Timilsena, Y.P.; Adhikari, B. Book chapter Spray drying. In Drying Technologies or Foods: Fundamentals \& Applications; New India Publishing Agency: New Delhi, India, 2015; pp. 79-106.

20. Bakry, A.M.; Abbas, S.; Ali, B.; Majeed, H.; Abouelwafa, M.Y.; Mousa, A.; Liang, L. Microencapsulation of oils: A comprehensive review of benefits, techniques, and applications. Compr. Rev. Food Sci. Food Saf. 2016, 15, 143-182. [CrossRef]

21. Galanakis, C.M.; Kotisiou, K. Recovery of bioactive compounds from olive mill waste. In Olive mill Waste: Recent Advances for Sustainable Management; Elsevier: Amsterdam, The Netherlands, 2016; pp. 205-228.

22. Roleira, F.M.F.; Tavares-da-Silva, E.J.; Varela, C.L.; Costa, S.C.; Silva, T.; Garrido, J.; Borges, F. Plant derived and dietary phenolic antioxidants: Anticancer properties. Food Chem. 2015, 183, 235-258. [CrossRef] 
23. da Silva Carvalho, A.G.; da Costa Machado, M.T.; da Silva, V.M.; Sartoratto, A.; Rodrigues, R.A.F.; Hubinger, M.D. Physical properties and morphology of spray dried microparticles containing anthocyanins of jussara (Euterpe edulis Martius) extract. Powder Technol. 2016, 294, 421-428. [CrossRef]

24. Krishnaiah, D.; Sarbatly, R.; Nithyanandam, R. Microencapsulation of Morinda citrifolia L. extract by spray-drying. Chem. Eng. Res. Des. 2012, 90, 622-632. [CrossRef]

25. Danaei, M.; Dehghankhold, M.; Ataei, S.; Hasanzadeh Davarani, F.; Javanmard, R.; Dokhani, A.; Khorasani, S.; Mozafari, M. Impact of particle size and polydispersity index on the clinical applications of lipidic nanocarrier systems. Pharmaceutics 2018, 10, 57. [CrossRef] [PubMed]

26. Singh, R.; Lillard, J.W., Jr. Nanoparticle-based targeted drug delivery. Exp. Mol. Pathol. 2009, 86, $215-223$. [CrossRef]

27. Gomes, J.F.P.S.; Rocha, S.; Pereira, M.D.C.; Peres, I.; Moreno, S.; Toca-Herrera, J.; Coelho, M.A.N. Lipid/particle assemblies based on maltodextrin-gum arabic core as bio-carriers. Colloids Surf. B Biointerfaces 2010, 76, 449-455. [CrossRef]

28. Nawrocka, A.; Szymańska-Chargot, M.; Miś, A.; Wilczewska, A.Z.; Markiewicz, K.H. Effect of dietary fibre polysaccharides on structure and thermal properties of gluten proteins-A study on gluten dough with application of FT-Raman spectroscopy, TGA and DSC. Food Hydrocoll. 2017, 69, 410-421. [CrossRef]

29. Meng, Q.; Li, Y.; Xiao, T.; Zhang, L.; Xu, D. Antioxidant and antibacterial activities of polysaccharides isolated and purified from Diaphragma juglandis fructus. Int. J. Biol. Macromol. 2017, 105, 431-437. [CrossRef]

30. Iurckevicz, G.; Marques, P.T.; Lima, V.A. Análise Química e Quimiométrica de Matrizes de Amido Modificado por Trimetafosfato de Sódio. Rev. Virtual Quim 2017, 9, 1462-1480. [CrossRef]

31. Kagimura, F.Y.; da Cunha, M.A.A.; Theis, T.V.; Malfatti, C.R.M.; Dekker, R.F.H.; Barbosa, A.M.; Teixeira, S.D.; Salomé, K. Carboxymethylation of $(1 \rightarrow 6)$ - $\beta$-glucan (lasiodiplodan): Preparation, characterization and antioxidant evaluation. Carbohydr. Polym. 2015, 127, 390-399. [CrossRef]

32. Ballesteros, L.F.; Ramirez, M.J.; Orrego, C.E.; Teixeira, J.A.; Mussatto, S.I. Encapsulation of antioxidant phenolic compounds extracted from spent coffee grounds by freeze-drying and spray-drying using different coating materials. Food Chem. 2017, 237, 623-631. [CrossRef]

33. Surikutchi, B.T.; Patil, S.P.; Shete, G.; Patel, S.; Bansal, A.K. Drug-excipient behavior in polymeric amorphous solid dispersions. J. Excipients Food Chem. 2013, 4, 70-94.

34. Horst, M.F.; Coral, D.F.; van Raap, M.B.F.; Alvarez, M.; Lassalle, V. Hybrid nanomaterials based on gum arabic and magnetite for hyperthermia treatments. Mater. Sci. Eng. C 2017, 74, 443-450. [CrossRef] [PubMed]

35. Ali, A.; Ganie, S.A.; Mazumdar, N. A new study of iodine complexes of oxidized gum arabic: An interaction between iodine monochloride and aldehyde groups. Carbohydr. Polym. 2018, 180, 337-347. [CrossRef] [PubMed]

36. Gómez-Ordóñez, E.; Rupérez, P. FTIR-ATR spectroscopy as a tool for polysaccharide identification in edible brown and red seaweeds. Food Hydrocoll. 2011, 25, 1514-1520. [CrossRef]

37. Alipour, H.J.; Rezaei, M.; Shabanpour, B.; Tabarsa, M. Effects of sulfated polysaccharides from green alga Ulva intestinalis on physicochemical properties and microstructure of silver carp surimi. Food Hydrocoll. 2018, 74, 87-96. [CrossRef]

38. Quintanilha, R.C.; Orth, E.S.; Grein-Iankovski, A.; Riegel-Vidotti, I.C.; Vidotti, M. The use of gum arabic as "Green" stabilizer of poly(aniline) nanocomposites: A comprehensive study of spectroscopic, morphological and electrochemical properties. J. Colloid Interface Sci. 2014, 434, 18-27. [CrossRef] [PubMed]

39. Anjos, O.; Campos, M.G.; Ruiz, P.C.; Antunes, P. Application of FTIR-ATR spectroscopy to the quantification of sugar in honey. Food Chem. 2015, 169, 218-223. [CrossRef] [PubMed]

40. Xu, J.; Liu, W.; Yao, W.; Pang, X.; Yin, D.; Gao, X. Carboxymethylation of a polysaccharide extracted from Ganoderma lucidum enhances its antioxidant activities in vitro. Carbohydr. Polym. 2009, 78, 227-234. [CrossRef]

41. Wang, J.; Zhang, L. Structure and chain conformation of five water-soluble derivatives of a $\beta$-Dglucan isolated from Ganoderma lucidum. Carbohydr. Res. 2009, 344, 105-112. [CrossRef]

42. Castro-Cabado, M.; Casado, A.L.; San Román, J. Bio-based thermosets: Effect of the structure of polycarboxylic acids on the thermal crosslinking of maltodextrins. Eur. Polym. J. 2016, 78, 91-105. [CrossRef]

43. Smrčková, P.; Horský, J.; Šárka, E.; Koláček, J.; Netopilík, M.; Walterová, Z.; Kruliš, Z.; Synytsya, A.; Hrušková, K. Hydrolysis of wheat B-starch and characterisation of acetylated maltodextrin. Carbohydr. Polym. 2013, 98, 43-49. [CrossRef] [PubMed] 
44. Silva, D.A.; Costa, D.A.; Silva, D.F.; Souza, M.F.V.; Agra, M.F.; Medeiros, I.A.; Barbosa-Filho, J.M.; Braz-Filho, R. Flavonóides glicosilados de Herissantia tiubae (K. Schum) Brizicky (Malvaceae) e testes farmacológicos preliminares do canferol 3,7-di-O- $\alpha$-L-ramnopiranosídeo. Braz. J. Pharmacogn. 2005, 15, 23-29. [CrossRef]

45. Santos, A.M.P.; Bertoli, A.C.; Carolina, A.; Borges, C.P.; Gomes, R.A.B.; Garcia, J.S.; Trevisan, M.G. New organomineral complex from humic substances extracted from poultry wastes: synthesis, characterization and controlled release study. J. Braz. Chem. Soc. 2018, 29, 140-150. [CrossRef]

46. Lima, I.A.D.; Khalil, N.M.; Tominaga, T.T.; Lechanteur, A.; Sarmento, B.; Mainardes, R.M. Mucoadhesive chitosan-coated PLGA nanoparticles for oral delivery of ferulic acid. Artif. Cells Nanomed. Biotechnol. 2018, 1-10. [CrossRef] [PubMed]

47. Su, S.-F.; Chou, C.-H.; Kung, C.-F.; Huang, J. In vitro and in vivo comparison of two diclofenac sodium sustained release oral formulations. Int. J. Pharm. 2003, 260, 39-46. [CrossRef]

48. Gibaldi, M.; Feldman, S. Establishment of sink conditions in dissolution rate determinations. Theoretical considerations and application to nondisintegrating dosage forms. J. Pharm. Sci. 1967, 56, 1238-1242. [CrossRef] [PubMed]

49. Korsmeyer, R.W.; Gurny, R.; Doelker, E.; Buri, P.; Peppas, N.A. Mechanisms of solute release from porous hydrophilic polymers. Int. J. Pharm. 1983, 15, 25-35. [CrossRef]

50. Siepmann, J.; Peppas, N.A. Higuchi equation: Derivation, applications, use and misuse. Int. J. Pharm. 2011, 418, 6-12. [CrossRef]

51. Herculano, E.D.; de Paula, H.C.B.; de Figueiredo, E.A.T.; Dias, F.G.B.; Pereira, V.D.A. Physicochemical and antimicrobial properties of nanoencapsulated Eucalyptus staigeriana essential oil. LWT Food Sci. Technol. 2015, 61, 484-491. [CrossRef]

52. Agrawal, A.; Purwar, R. Swelling and drug release kinetics of composite wound dressing. Indian J. Fibre Text. Res. 2018, 43, 104-111.

53. Fu, Y.; Kao, W.J. Drug release kinetics and transport mechanisms of non-degradable and degradable polymeric delivery systems. Expert Opin. Drug Deliv. 2010, 7, 429-444. [CrossRef] [PubMed]

54. Rigter, P.L.; Peppas, N.A. A simple equation for description of solute relase I. Fickian and non-fickian release from non-swellable devices in the form of slabs, spherer, cylinders or discs. J. Control. Release 1987, 5, 23-36.

55. Romero, A.I.; Villegas, M.; Cid, A.G.; Parentis, M.L.; Gonzo, E.E.; Bermúdez, J.M. Validation of kinetic modeling of progesterone release from polymeric membranes. Asian J. Pharm. Sci. 2018, 13, 54-62. [CrossRef]

56. Siepmann, J.; Peppas, N. Modeling of drug release from delivery systems based on hydroxypropyl methylcellulose (HPMC). Adv. Drug Deliv. Rev. 2001, 48, 139-157. [CrossRef]

57. Prajapati, S.K.; Richhaiya, R.; Singh, V.K.; Singh, A.K.; Kumar, S.; Chaudhary, R.K. Formulation and evaluation of once daily sustained release matrix tablets of aceclofenac using natural gums. J. Drug Deliv. Ther. 2012, 2, $16-24$.

58. Sitta, D.L.A.; Guilherme, M.R.; da Silva, E.P.; Valente, A.J.M.; Muniz, E.C.; Rubira, A.F. Drug release mechanisms of chemically cross-linked albumin microparticles: Effect of the matrix erosion. Colloids Surf. B Biointerfaces 2014, 122, 404-413. [CrossRef] [PubMed]

59. Bruschi, M.L. 5-Mathematical models of drug release. In Strategies to Modify the Drug Release from Pharmaceutical Systems; Elsevier: Amsterdam, The Netherlands, 2015; pp. 63-86, ISBN 9780081001127.

60. Marques, G.R.; Borges, S.V.; de Mendonça, K.S.; de Barros Fernandes, R.V.; Menezes, E.G.T. Application of maltodextrin in green corn extract powder production. Powder Technol. 2014, 263, 89-95. [CrossRef]

61. de Barros Fernandes, R.V.; Borges, S.V.; Botrel, D.A. Gum arabic/starch/maltodextrin/inulin as wall materials on the microencapsulation of rosemary essential oil. Carbohydr. Polym. 2014, 101, 524-532. [CrossRef]

62. Teixeira, M.I.; Andrade, L.R.; Farina, M.; Rocha-Leão, M.H.M. Characterization of short chain fatty acid microcapsules produced by spray drying. Mater. Sci. Eng. C 2004, 24, 653-658. [CrossRef]

63. Rezende, T.; Corrêa, J.; Aarestrup, B.; Aarestrup, F.; de Sousa, O.; da Silva Filho, A. Protective effects of Baccharis dracunculifolia leaves extract against carbon tetrachloride- and acetaminophen-induced hepatotoxicity in experimental animals. Molecules 2014, 19, 9257-9272. [CrossRef]

64. de Sousa, J.P.B.; da Silva Filho, A.A.; Bueno, P.C.P.; Gregório, L.E.; Furtado, N.A.J.C.; Jorge, R.F.; Bastos, J.K. A validated reverse-phase HPLC analytical method for the quantification of phenolic compounds in Baccharis dracunculifolia. Phytochem. Anal. 2009, 20, 24-32. [CrossRef] [PubMed]

65. Dias, M.P.; Nozari, R.M.; Santarém, E.R. Herbicidal activity of natural compounds from Baccharis spp. on the germination and seedlings growth of Lactuca sativa and Bidens pilosa. Allelopath. J. 2017, 42, 21-36. [CrossRef] 
66. Cunha, M.A.A.; Turmina, J.A.; Ivanov, R.C.; Barroso, R.R.; Marques, P.T.; Fonseca, E.A.I.; Fortes, Z.B.; Dekker, R.F.H.; Khaper, N.; Barbosa, A.M. Lasiodiplodan, an exocellular $(1 \rightarrow 6)-\beta$-d-glucan from Lasiodiplodia theobromae MMPI: production on glucose, fermentation kinetics, rheology and anti-proliferative activity. J. Ind. Microbiol. Biotechnol. 2012, 39, 1179-1188. [CrossRef] [PubMed]

67. Salgado, M.; Rodríguez-Rojo, S.; Alves-Santos, F.M.; Cocero, M.J. Encapsulation of resveratrol on lecithin and $\beta$-glucans to enhance its action against Botrytis cinerea. J. Food Eng. 2015, 165, 13-21. [CrossRef]

68. Aburto, L.C.; Tavares, D.D.Q.; Martucci, E.T. Microencapsulação de óleo essencial de laranja. Food Sci. Technol. 1998, 18, 45-48. [CrossRef]

69. Saikia, S.; Kumar Mahnot, N.; Lata Mahanta, C. Optimisation of phenolic extraction from Averrhoa carambola pomace by response surface methodology and its microencapsulation by spray and freeze drying. Food Chem. 2015, 171, 144-152. [CrossRef]

70. Singleton, V.L.; Rossi, J.A. Colorimetry of total phenolics with phosphomolybdic-phosphotungstic acid reagents. Am. J. Enol. Vitic. 1965, 16, 144-158.

71. Brand-Williams, W.; Cuvelier, M.E.; Berset, C. Use of a free radical method to evaluate antioxidant activity. LWT Food Sci. Technol. 1995, 28, 25-30. [CrossRef]

72. Huang, M.-H.; Huang, S.-S.; Wang, B.-S.; Wu, C.-H.; Sheu, M.-J.; Hou, W.-C.; Lin, S.-S.; Huang, G.-J. Antioxidant and anti-inflammatory properties of Cardiospermum halicacabum and its reference compounds ex vivo and in vivo. J. Ethnopharmacol. 2010, 133, 743-750. [CrossRef]

73. Wootton-Beard, P.C.; Ryan, L. A beetroot juice shot is a significant and convenient source of bioaccessible antioxidants. J. Funct. Foods. 2011, 3, 329-334. [CrossRef]

74. Rosa, M.F.; Vilhena, R.D.O. Dissolução intrínseca: conceito e aplicações na indústria farmacêutica. Rev. Eletrônica Farmácia 2012, IX, 49-61. [CrossRef]

Sample Availability: Samples of the compounds are available from the authors.

(C) 2019 by the authors. Licensee MDPI, Basel, Switzerland. This article is an open access article distributed under the terms and conditions of the Creative Commons Attribution (CC BY) license (http://creativecommons.org/licenses/by/4.0/). 